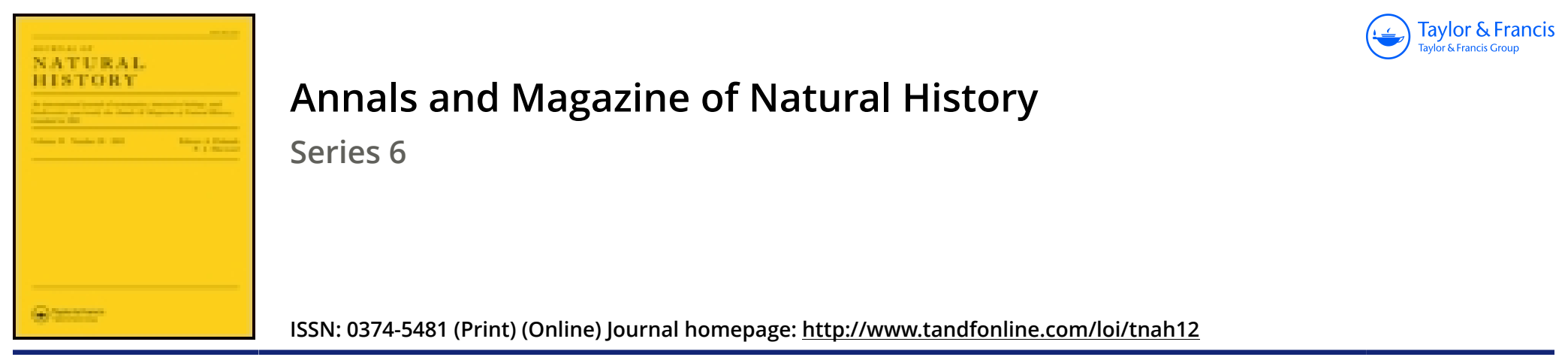

\title{
LIII.-Notes on the Palæozoic Bivalved Entomostraca.-No. XXV. On some Silurian Ostracoda from Gothland
}

\section{Prof. T. Rupert Jones F.R.S. F.G.S.}

To cite this article: Prof. T. Rupert Jones F.R.S. F.G.S. (1888) LIII.-Notes on the Palæozoic Bivalved Entomostraca.-No. XXV. On some Silurian Ostracoda from Gothland, Annals and Magazine of Natural History, 1:6, 395-411, DOI: 10.1080/00222938809460756

To link to this article: http://dx.doi.org/10.1080/00222938809460756

曲 Published online: 12 Oct 2009.

Submit your article to this journal $\pi$

Џll Article views: 5

Q View related articles $\triangle$

Citing articles: 2 View citing articles 
Setæ in four rows of pairs; dorsal setæ (in posterior region of body) much longer than ventral. Nephridiopores in front of ventral setæ. Two pairs of spermathecæ in segments seven and eight.

\section{EXPLANATION OF PLATE XXIII.}

Fig. 1. Phreoryctes Smithii, nat. size.

Fig. 2. Anterior segments from ventral aspect, magnified. $s p$, spermathecal pores, $\delta$ openings of vasa deferentia, $q$ openings of oviducts.

Fig. 3. Genital segments. $t$, testes; o, ovaries; v.d, vasa deferentia ; $o . d$, oviducts; $s p$, spermathecæ; $s$, setæ; $n$, nerve-cord.

Fig. 4. Fragment of testis, highly magnified.

Fig. 5. Fragment of ovary, highly magnified.

Fig. 6. Section through funnel of vas deferens. st, septum ; $f$, funnel; $v . d$, vas deferens.

Fig. 7. Section through one of posterior segments. $s$, setæ; n, nervecord ; $a l$, intestine ; $d . v$, dorsal vessel; $v . v$, ventral vessel ; $n p$, nephridium.

Fig. 8. Surface view of the nephridiopore (np) and setro (s).

Fig. 9. Spermatheca, transverse sections. $a$, near to external orifice; $b$,

Fig. 10. Seta. near distal end.

\section{LIII.-Notes on the Palcoozoic Bivalved Entomostraca.- No. XXV. On some Silurian Ostracoda from Gothland*. By Prof. T. Rupert Jones, F.R.S., F.G.S.}

[Plates XXI. \& XXII.†]

Prof. Gustav Lindström, of the State Museum, Stockholm, having confided to me in $\mathbf{1 8 8 6}$ a fine series of Ostracoda from the Silurian rocks of Gothland for examination, I had much pleasure in 1887 in comparing them with such as are known from other countries and in determining what seemed to me to be their generic and specific alliances. Late researches among the British species, especially those collected by Messrs. J. Smith and G. R. Vine in Shropshire $\neq$, enabled me to arrive at conclusions more confidently than I could otherwise have done; and the results were given by me in the

* For No. XXIV. see Ann. \& Mag. Nat. Fjst. for June 1887.

+ These Plates have been drawn with the aid of a grant from the Royal Society for illustrating the fossil Entomostraca.

$\ddagger$ Ann. \& Mag. Nat. Hist. for April 1886, May 1886, March 1887, and June 1887. 

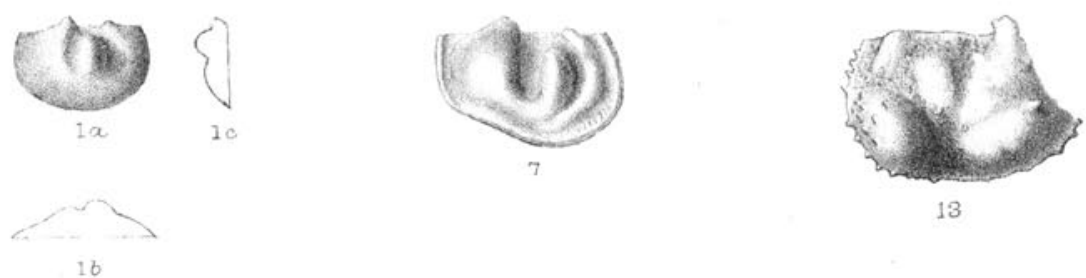

13
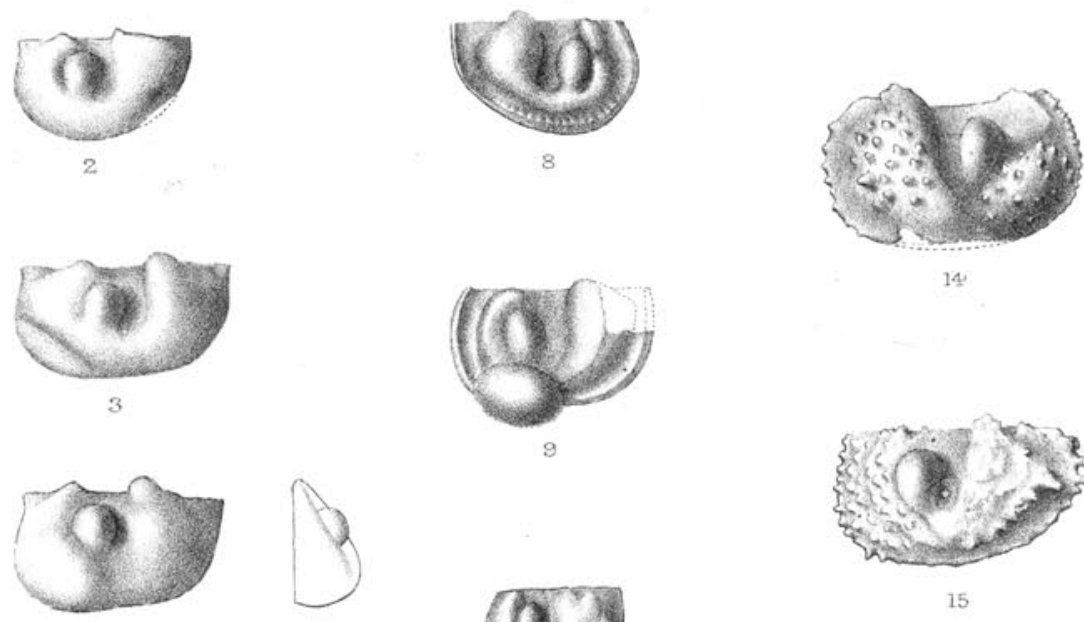

$4 \alpha$

4.0

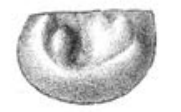

14

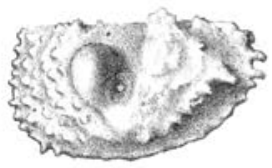

15

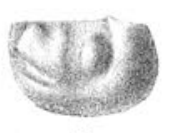

11
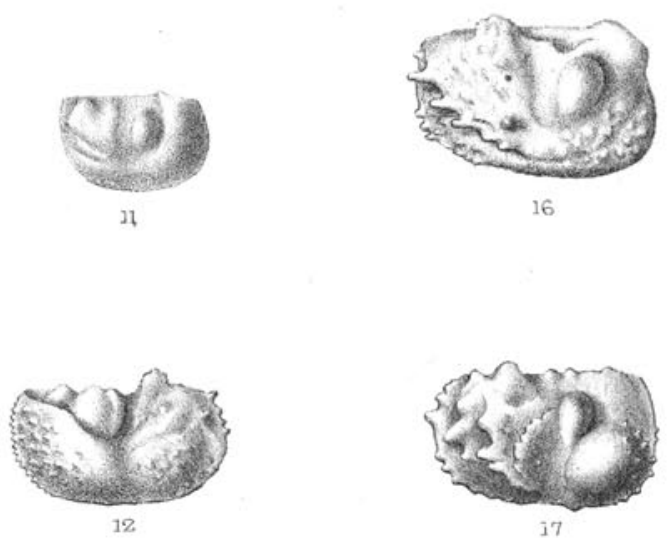

West,Nemnan \& Co imp.

ECKnight hith

Scandinavian Ostracoda. 

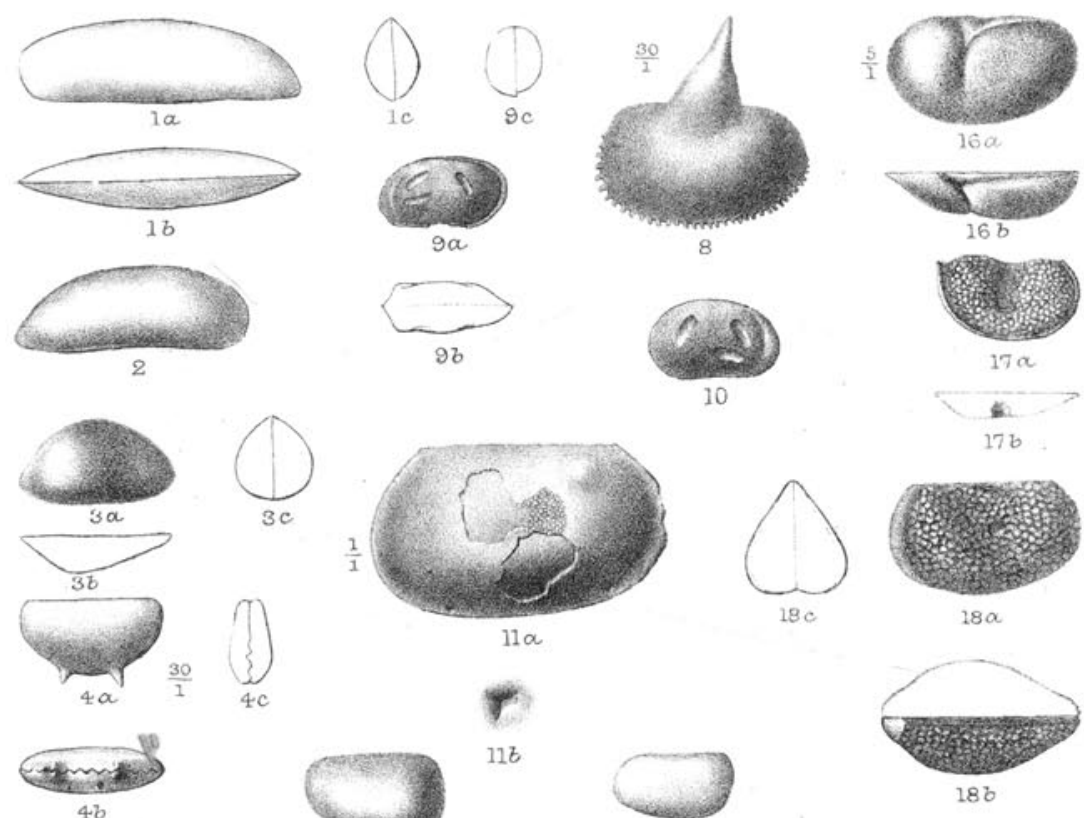
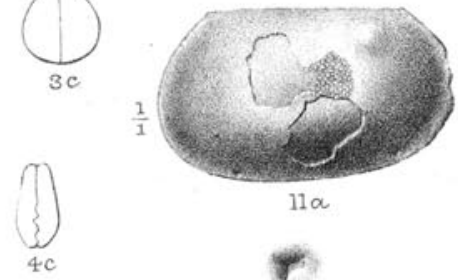

$11 a$
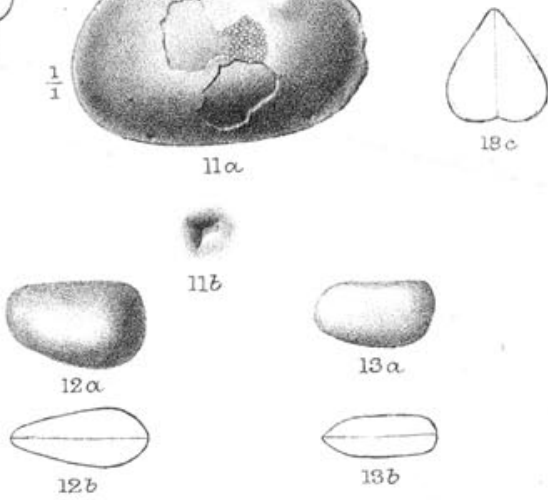

$18 \mathrm{c}$

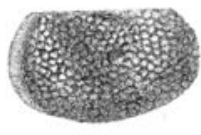

$18 \alpha$

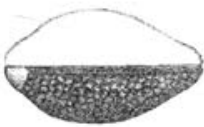

$18 b$

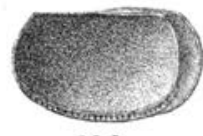

$18 \alpha$

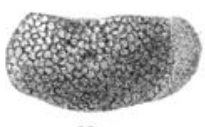

$19 \alpha$

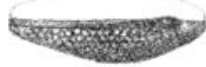

$19 b$
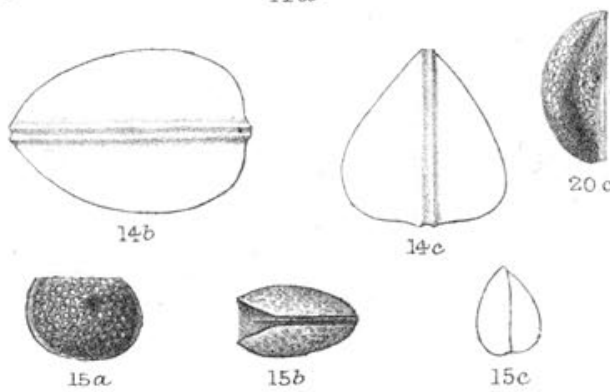

$15 \mathrm{c}$

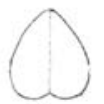

$19 c$

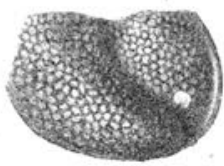

$20 a$

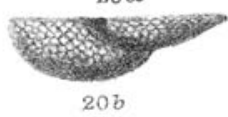

West, Nesmman \& Co imp

Scandinavian Ustracoda. 
privately-printed 'Notes on some Silurian Ostracoda from Gothland,' 8vo, Stockholm, 1887.

These Scandinavian specimens have now been carefully figured in the accompanying Plates, and some figures and descriptions of other specimens from Gothland have been added, as well as further remarks on the alliances of the already known species.

Mr. C. D. Sherborn, F.G.S., has helped me in sketching and collating the specimens sent from Stockholm. Several exquisite drawings executed by $\mathrm{Hr}$. C. Hedelin and forwarded by Dr. Lindström in 1886 have supplied the basis for some of my determinations of species.

\section{Macrocypris, G. S. Brady, 1867. (Ann. \& Mag. Nat. Hist. ser. 5, vol. xix. 1887, p. 178.)}

\section{Macrocypris Vinei, Jones. (Pl. XXII. tigs. $1 a, 1 b, 1 c, 2$.)}

Macrocypris Vinei, Jones, op. cit. p. 179, pl. iv. figs. 1-3, and woodeut, p. 179; Silur. Ostrac. Gothland, 1887, p. 6.

Careful drawings sent to me from Stockholm represent Macrocypris Vinei, Jones. The Swedish form, however (see figs. $1 a, b, c$ ), is slightly longer, has a slightly less orbicular end-view, and is more gracefully curved on the postero-dorsal slope; otherwise fig. 2 of pl. iv. referred to above very closely matches the drawing sent from Stockholm.

One specimen (Pl. XXII. fig. 2) among those sent to me in 1886 also comes within the limits of form characteristic of Macrocypris Vinei.

This species occurs rather copiously in the shale at Fröjel * (of the Wenlock series).

Note.-Cytheropsis siliqua, Jones (Ann. \& Mag. Nat. Hist. April 1858, p. 249, pl. x. fig. 6), is possibly figured in a reversed position, that is, with its dorsal edge downwards, and may really be a Macrocypris squeezed and broken. If so, being about 2 millim. in length, it would not be very different from the Scandinavian specimen (Pl. XXII. figs. $1 a, b, c$ ), which is 2 millim. long; fig. 2 shows an individual $1 \frac{1}{2}$ millim. long. Of the English specimens (op. cit. March 1887, pl. iv.) tig. 2 is $1 \frac{1}{3}$ millim. and fig. 3 is $1 \frac{3}{4}$ millim. in length.

* For the localities mentioned in this paper, as regards the Silurian Ostracoda of Gothland, see the geological map appended to Prof. Lindström's paper on the Silurian strata of that island, in the Neues Jahrb. für Minexal. \&c. 1888 , vol. i. pp. 147 \&c. pl. v. 
A group of Silurian Macrocyprides, such as M. Vinei, might at first sight be thought to be comparable with such a group of the Carboniferous Bairdia subelongata as described and figured in the Quart. Journ. Geol. Soc. vol. xxxv. 1879, p. 573, pl. xxx. figs. 1-11 and 16 (especially figs. 1 and 7 ); but however near an approach they may seem to make, the Macrocyprides have not the characteristic Bairdian outline of the postero-dorsal border. They also have the right valve larger than the left.

\section{Pontocypris, G. O. Sars, 1865.}

(Ann. \& Mag. Nat. Hist. ser. 5, vol. xix. 1887, p. 182.)

\section{Pontocypris Mawii, Jones. (Pl. XXII. figs. $3 a, 3 b, 3 c$.)}

Pontocypris Mawvi, Jones, loc. cit. pl. iv. figs. 4-6.

A few examples with Bythocypris Hollii came from the Fröjel shale. The specimen here figured differs slightly from the type in the convexity of the posterior third. 'The hinder border in fig. $3 a$ is not specially depressed, but being somewhat translucent shows the inner lamina.

III. Bythocrpris, G. S. Brady, 1880.

(Ann. \& Mag. Nat. Hist. ser. 5, vol. xix. 1887, p. 184.)

\section{Bythocypris symmetrica, Jones.}

Six specimens sent in 1886, showing slight modifications of outline, agree sufficiently well with Bythocypris symmetrica, Jones (op. cit. p. 186, pl. vii. figs. 3 and 4), for them to be referred to that species (Silur. Ostrac. Gothland, 1887, p. 6). From Fröjel.

\section{Bythocypris concinna, Jones.}

Bythocypris concinna, Jones, Ann. \& Mag. Nat. Hist. ser. 5, vol. xix. p. 186, pl. v. fig. 6; Silur. Ostrac. Gothland, 1887, p. 6.

Judging from the drawings sent from Stockholm, this species is represented in the Stockholm Collection. This is one of the most widely spread species, found in the uppermost strata of Estergarn, Linde klint, and Hoburg; and in the shale of Stora Carlsö. 


\section{Bythocypris Hollii, Jones.}

Bythocypris Hollii, Jones, Ann. \& Mag. Nat. Hist. ser. 5, vol. xix. p. 184, pl. v. figs. 1 and 2 , and pl. vi. figs. 3 and 4 ; Sil. Ostrac. Gothland, 1887, p. 6.

This fine species is represented in the drawings sent to me by Prof. Lindström; and several examples were among the specimens obtained from the shale or marl of the brickyard at Fröjel and sent to me from Stockholm in 1886.

Note.-Cytheropsis concinna, Jones (Ann.\&Mag. Nat. Hist. ser. 3, vol. i. 1858, pp. 249 and 254, pl. x. figs. 3 and 4), was referred, I now think erroneously, to the smooth Primitioe, as $P$. muta (op. cit. vol. xvi. 1865 , p. 425 , and ser. 4, vol. iii. 1869, p. 222). It was probably figured in a reversed position; and if looked at in the other position it may be taken for a Bythocypris, approaching B. testacella (Ann. \& Mag. Nat. Hist. March 1887, p. 186, pl. v. fig. 5) in shape, though rather larger, being $1 \frac{1}{2}$ millim. long, instead of a very little more than 1 millim. "C. concinna," figured and described by Dr. Kolmodin (Sverg. Silur. Ostrac. 1869, p. 21, pl. O. fig. 15), which is $1 \frac{1}{2}$ millim. long, may also be included in the same category, as a possible Bythocypris, if the convex border be regarded as dorsal instead of ventral.

\section{Kleedenia, Jones \& Holl, 1886.}

(Ann. \& Mag. Nat. Hist. ser. 5, vol. xvii. pp. 347 and 362.)

\section{Klodenia apiculata, sp. nov. (Pl. XXI. figs. 1-5.)}

This Scandinavian Klodenia, from the uppermost strata of Slite, in Gothland, is not far removed as to its general shape and features from $K$. Wilckensiana *. In some individuals of the new species the valves are much more oblong (figs. 3 and 4) and the dorsal angles are generally more acute. The front and hind lobes rise much higher, reaching beyond the dorsal border; and this formation suggests the name apiculata. The middle lobe, on the contrary, does not rise so high

* This also belongs to the Silurian rocks of Scandinavia, being found as well in place as in the drifted blocks of limestone in North Germany; Ann. \& Mag. Nat. Hist. ser. 2, vol. xvi. pp. 82 and 89, pl. v. figs. 17-19; figs. 20,21 , represent $K$. plicata, described at p. 90 as a variety, but sufficiently different as compared with the two other forms to be regarded as specifically distinct. See A. Krause, in Zeitschr. deutsch. geol. Ges, 1877 , p. 35 , pl. i. figs, $18 a, b(18 b, K$. plicata), and G. Reuter, op. eit. 1885 , p. 647 , pl. xxvi. fig. 23 , on the distribution of these Klodenia. 
towards the back edge, but huddles itself low down within the curve of the anterior lobe. The semilunar furrow, forming a narrow ridge or fold in the posterior region of $K$. Wilckensiana, is absent in $K$. apiculata. In an old individual of the latter (fig. 5) there is an uncertain appearance of a slight furrow within the anterior border, but it probably resulted from an accident. Figs. 1-5 show the gradations of form between the youngest (smallest) and the oldest individuals that have come to hand; and although no two are exactly alike, they all possess the same essential characters. Figs. $4 a, b, c$, represent a valve having the antero-ventral region hypertrophied, as is usual among some species of Beyrichice and in $K$. Wilckensiana ${ }^{*}$. The specimens of $K$. apiculata, white and well preserved, are not rare in the uppermost Silurian strata at Slite, Gothland.

\section{Beyrichia, M'Coy, 1846.}

(Ann. \& Mag. Nat. Hist. ser. 5, vol. xvii. 1886, p. 345.)

\section{Beyrichia clavata, Kolmodin. (Pl. XXI. figs. 6-9.)}

Beyrichia clavata, Kolmodin, Bidrag till Kännedomen om Sverges Siluriska Ostracoder, Akad. Afhandl. \&c., 1869, p. 18, pl. O. fig. 10; Jones, Silur. Ostrac. Gothland, 1887, p. 2.

This Beyrichia seems to be the same as Haidenhain's fig. 12, pl. i. (Zeitschr. deutsch. geol. Gesell. vol. xxi. 1869, p. 171), which he describes as $B$. Kloedeni; also fig. 11 in Angelin's unpublished "tab. A."

It differs from the ordinary $B$. Kloedeni in the relative position and size of its lobes. The gigot-lobe is broad and triangular and often compressed above and almost apiculate; the front lobe is very narrow and curved, and the middle lobe lies down close in the concavity of the latter. The surface has a minute and variable granulation. The marginal area is broad and hollow, and its ventral portion has a series of small, impressed, radiating marks, slighter in some specimens than in others, and the outer rim is strong.

This is an abundant species, and among about one hundred specimens sent to me from Stockholm the arrangement and relative size of the lobes are remarkably persistent among individuals from 1 to $2 \frac{1}{2}$ millim. in length. It is plentiful in the shales of Eksta and Fröjel.

* Ann. \& Mag. Nat. Hist. ser. 5, vol, xvii. pp. 340-342. 
Some individuals have the hypertrophied lobe (fig. 9) frequently seen in some species of Beyrichia (see Ann. \& Mag. Nat. Hist. ser. 5, vol. xvii. pp. 339-343). There are about twelve of these accompanying the others.

Several years ago I received specimens of Silurian Beyrichioe found at Fröjel and Estergarn, in Gothland, from Dr. Lindström, and amongst them $\vec{B}$. clavata occurs, sometimes with the hypertrophied antero-ventral lobe.

Note.-The figure given of Beyrichia Kloedeni, $\mathrm{M}^{\prime} \mathrm{Coy}$, in the Brit. Pal. Foss. Cambr. Mus. 1851, pl. 1 E. fig. 2, has a considerable resemblance to $B$. clavata, Kolm.; so also has Haswell's figure of $B$. Klodeni (Silur. Formation Pentland Hills, 1865, pl. iii. fig. 12). In each case, however, I believe this resemblance is due to the inferior portraiture of the specimen. Having been favoured with an opportunity of studying $M^{\prime}$ Coy's type specimen, I find that it is a fairly good internal cast of an ordinary adult $B$. Kloedeni, with three lobes really having proportions and distances different from those in B. clavata.

2. Beyrichia Kloedeni, M'Coy, var. granulata, Jones.

Beyrichia Klocdeni, M'Coy, var. granulata, Jones, Ann. \& Mag. Nat. Hist. ser. 5 , vol. xvii. 1886, p. 350, pl. xii. fig. 2 ; Silur. Ostrac. Gothland, 1887, p. 2.

Of this form, which is a good type of B. Kloedeni, except that it has a rough instead of a smooth surface, there was only one in the set sent in 1886, and I had one which Prof. Lindström gave me some years ago. Both have the hypertrophied lobe.

Except in the roughness of the surface and the want of tubercles on the margin these specimens closely match fig. 12 of Angelin's unpublished "tab. A."

Found at CEstergarn and Fröjel.

\section{Beyrichia Klodeni, $\mathrm{M}^{6} \mathrm{Coy}$, var. verruculosa, nov.}

Three specimens among those from Eksta and Fröjel are referable to $B$. Kloedeni, but are rather longer ( 3 millim. in length) than usual, and have a coarse granulation of somewhat scattered tubercles over the surface and on the thick free margins. The lobes are well formed and distinct, the middle lobe slightly united below with the other two. 'I'he fig. 13 in Angelin's unpublished "tab. A " is of the same kind, but its features are rather masked by the hypertrophy of its antero- 
ventral lobe. Fig. 21 of the same plate is possibly a larger (older) individual of the same variety.

Boll's B. spinigera (Archiv Ver. Fr. Naturges. Mecklenburg, 1862, p. 133, pl. i. fig. 7) is much like the variety under notice, but the middle lobe is quite distinct from the other two, and the margin has a different ornamentation. B. nodulosa, Boll (l. c. fig. 6), also belongs to the same category, but the lobes have different proportions and position. B. protuberans, Boll (l.c. fig. 6), is a weaker variety, tuberculate only on the hinder lobe, and deformed in front by the usual hypertrophied lobe.

\section{Beyrichia Klodeni, $M^{\prime}$ Coy, var. antiquata, Jones.}

Beyrichia Kloedeni, $\mathrm{M}^{\prime} \mathrm{Coy}$, var. antiquata, Jones, Ann. \& Mag. Nat. Hist. ser. 2, vol. xvi. 1855, p. 167, pl. vi. fig. 8; Palæoz. Biv. Entom., Geol. Assoc. 1869, p. 12, pl. xiv. fig. 7 (in both instances the sinistral valve is figured and is erroneously termed the dextral); Geol. Mag. 1881, p. 345, pl. x. fig. 11; Silur. Ostrac. Gothland, 1887, p. 2.

Some years ago I received this specimen from Prof. Lindström. It occurred in the shale of Estergarn, Gothland.

Fig. 14 in Angelin's unpublished "tab. A" is evidently B. Klodeni, var. antiquata.

\section{Beyrichia Kloedeni, M'Coy, var. tuberculata, Salter.}

(Geol. Mag. 1881, p. 345, pl, x. fig. 13 ; Ann. \& Mag. Nat. Hist. ser. 5, vol. xvii. 1886, p. 354, pl. xï. figs. 8,9; Silur. Ostrac. Gothland, 1887, p. 3.)

This variety is shown by one of the drawings sent from Stockholm. A few specimens were found in the uppermost limestone of Linde klint. From the shale at Fröjel I have one specimen, sent some years ago.

B. Klocdeni, var. tuberculata, was first described and figured by Mr. J. W. Salter in 1848 (Mem. Geol. Survey, vol. ii. part 1 , p. 352, pl. viii. figs. 14,15 ) as " $B$. tuberculata, Klöden." Figs. 14 and $14 a$ represent the outside of the valve, from the Wenlock Limestone at Lindells, Woolhope; figs. 15 and $15 a$ show an internal cast from the Wenlock Shale, ac Tynewydd, south of Llandovery.

In this variety the width of the ventral margin and the amount of tuberculation vary very much with individuals.

In Angelin's unpublished "tab. A," fig. 18 evidently represents this variety.

\section{Beyrichia Bolliana-umbonata, Reuter.} (Pl. XXI. figs. 10 \& 11.)

Some specimens under notice are probably identical with 
Reuter's above-mentioned variety of his $B$. Bolliana (Zeitschr. deutsch. geol. Ges. vol. xxxvii. 1885, p. 616, pl. xxvi. fig. 21), although it has a finely granulated surface. I do not agree with Hr. Reuter's synonymy for this form (Silur. Ostrac. Gothland, 1887, p. 3).

The ventral margin differs in development with individuals. Two were sent to me by Prof. Lindström in 1886 from Fröjel.

\section{Beyrichia tuberculata (Klöden) and varr.}

(Pl. XXI. figs. 12-17.)

For B. tuberculata (Klöden) see Ann. \& Mag. Nat. Hist. ser. 5, vol. xvii. p. 347, pl. v. figs. 4-9 (figs. 10-11, var. nuda, is the same as B. Kochii, Boll). See also op. cit. April 1886, pp. 347-349, for synonyms, correcting as above.

\section{7*. Beyrichia tuberculata, vera (senex). (Pl. XXI. fig. 12.)}

In PI. XXI. fig. 12 we have what I believe to be an old individual well developed, but unfortunately broken at its antero-dorsal region, where the middle lobe and the dorsal portion of the front lobe have been displaced inwards by pressure. Klöden's fig. 22 comes nearest among published figures to this specimen; but the lobes are more divided and the hinder lobe more distinctly sulcate in that figure, and our specimen is denticulate on the front margin and has a few prickles behind. Boll's fig. $1 a$ of $B$. tuberculata has the lobes still more distinct; the hinder lobe exhibits its three characteristic segments; the front lobe is distorted by hypertrophy; and the margin is broad and somewhat tuberculate in front. The Nova-Scotian specimen (Geol. Mag. 1881, pl. x. fig. 10) is another of these full-grown and coarsefeatured individuals, retaining the essential characters, however much modified they may be by age.

\section{7**. Beyrichia tuberculata, var. spicata, nov.}

(Pl. XXI. figs. 13, 14.)

Differing, it may be, by advanced growth only, fig. 13 shows isolated spikes or prickles on its lobes and sharp teeth both along the front border and on what remains of the hind margin. The lobes are distinct; the anterior lobe is modified by an enlargement of its lower moiety; the posterior lobe is broken, but shows some signs of its normal sulcation, and has a projection on its dorsal edge as in fig. 12 . 
In fig. 14 (a right valve) the prickles of the surface are more numerous; the hinder lobe shows no sulcation, as in the var. antiquata (Ann. \& Mag. Nat. Hist. August 1855, p. 87, pl. v. fig. 12), and the upper moiety of the front valve is reduced to a narrow, curved, rugose ridge; the hind and front margins are denticulate.

\section{7 ***. Beyrichia tuberculata, var. foliosa, nov. (PI. XXI. figs. 15-17.)}

In figs. 15 and 16 the superficial isolated prickles are exaggerated into somewhat concentric rows of large and small spines, directed backwards on the posterior and forwards on the anterior part of the valve, and less regularly arranged tubercles occupy the inner slope of the hinder or gigot-lobe. The middle lobe is distinct, as in all the other specimens of these Beyrichioe; but the hinder lobe is no longer rounded and divided crosswise, and the front lobe is also obsolete or shapeless and overgrown with tubercles.

Fig. 17 has a still more extreme variation in its concentric overlapping growths of leaf-like, coarsely denticulated expansions over the hinder lobe, which retains the dorsal projection, seen also in figs. 12-15. The middle lobe is distinct and smooth; the front lobe is smooth and low above, but prominent and partially tuberculate in its lower moiety.

The originals of figs. 12-17 are well-preserved white specimens from the Uppermost Silurian strata of Slite, Gothland.

\section{LePerdit'ia, Rouault, 1851.}

(Ann. \& Mag. Nat. Hist. ser. 2, vol. xvii. 1856, p. 84, and ser. 5, vol. viii. 1881, p. 333 \&c.; Proc. Geol. Assoc. vol. 1x. 1886, p. 503.)

\section{Leperditia grandis, Schrenck. (Pl. XXII. figs. $11 a, 11$ b.) \\ (Silur. Ostrac. Gothland, 1887, p. 3.)}

This Leperditia is evidently a small individual of L. gran$d i s$, as described and figured by Fr. Schmidt in the Mém. Acad. Imp. Sci. St.-Pétersb. sér. 7, vol. xxi. 1873, p. 10, figs. 1-6a. According to him it is the same as F. Römer's L. gigantea.

This right valve, figured in the drawings sent from Stockholm, shows distinctly at its ventral margin the two minute 
pits, which Fr. Schmidt describes as perforating the valve; here, however, they appear to be only shallow pits.

From the lowest limestone beds of Estergarn.

VII. Thlipsura, Jones \& Holl, 1869.

(Ann. \& Mag. Nat. Hist. ser. 4, vol. iii. p. 213.)

1. Thlipsura v-scripta, J. \& H., var. discreta, Jones.

(Pl. XXII. figs. $9 a, 9 b, 9 c, 10$.)

Thlipsura v-scripta, J. \& H., var. discreta, Jones, Silur. Ostrac. Gothland, 1887, p. 6.

This species was described and its British variety figured in 1869 by Jones \& Holl (Ann. \& Mag. Nat. Hist. ser. 4, vol. iii. p. 214, pl. xv. fig. 3). See also op. cit. ser. 5, vol. xix. p. 403.

In the Swedish variety, of which about fifty specimens form part of the series sent to me in 1886, the front sulcus is oblique, being not quite perpendicular, and those on the hinder half of the valve keep slightly apart, not closing together to form the letter V completely. There is also a slight, curved, convex ridge within and parallel to the posterior margin; but it is not always well developed. Dr. Krause has figured this variety as Primitia minuta (Zeitschr. deutsch. geol. Ges. vol. xxix. p. 38, pl. i. fig. 19). Abundant in the shale of Fröjel.

VIII. Primitia, Jones \& Holl, 1865.

(Ann. \& Mag. Nat. Hist. ser. 3, vol, xvi. p. 415.)

\section{Primitia lavis, Jones. (Pl. XXII. figs. $12 a, 12 b$. )}

Primitia lavis (parte), Jones, Silur. Ostrac. Gothland, 1887, p. 4.

This is a smooth, subtriangular, somewhat Leperditioid form, straight on the back, rounded at the ends, but one of them much higher (broader) than the other. It appears to be new. The only group to which I can refer it is that of the smooth Primitio, such as $P$. matutina, semicircularis, obsoleta, ovata, and oblonga, in pl. xiii. Ann. \& Mag. Nat. Hist. ser. 3, vol. xvi. p. 423 \&c. It is convex mainly in the postero-ventral region. Its contact-edges are bevelled inwards, except along the straight edge, which seems to be the back and hinge-line. It would more closely resemble $P$.obsoleta, J.\&H., if it were shorter and less compressed anteriorly. Edge-view (fig. $12 b$ ) narrow-ovate. 
This may be provisionally known as P. loovis. Though the smooth Primitice pass by gradation into the sulcate forms, possibly a subgeneric term might be usefully applied to them.

So far as its outline is concerned $P$. leveis much resembles Leperditia tyraica, Fr. Schmidt; but its internal edges are not those of Leperditia, nor has it the special surface-characters of that genus.

Only two specimens (from the shale of Fröjel) were among those sent in 1886.

\section{Primitia stricta, sp. nov.}

(Pl. XXII. figs. $13 a, 13 b$.)

Primitia lacvis (parte), Jones, Silur. Ostrac. Gothland, 1887, p. 4.

More compressed than fig. 12, and with less height at the posterior third, this unique specimen is more oblong in outline, with parallel sides. Edge view (fig. $13 b$ ) narrow oblong, but acute in front and rounded behind. From Fröjel, in 1886 .

In shape this approximates to Primitia variolata, J. \& $\mathbf{H}$. (Ann. \& Mag. Nat. Hist. ser. 3, vol. xvi. p. 418, pl. xiii. fig. 6) ; but it is not so evenly rounded at the ends and has neither the sulcus nor the punctation. It is smooth, like the little P. matutina, J. \& H. (loc. cit. fig. 7), but differs from it in shape.

\section{Primitia valida, J. \& H.}

Primitia valida, J. \& H., Ann. \& Mag. Nat. Hist. ser. 5, vol. xvii. 1886, p. 409 , pl. xiv. tig. 7 , and vol, xix. p. 193, pl. vi. fig. 7 ; Silur. Ostrac. Gothland, 1887, p. 4.

In the Swedish specimens (of which twenty-four were sent in 1886) the reticulation of the surface is much more definite than in the British examples. There is also a distinct row of minute denticles along the ventral edge of each valve in many of the Swedish specimens.

From Fröjel.

4. Primitia grandis, Jones.

(Pl. XXII. figs. $14 a, 14 b, 14 c$.)

Primitia grandis, Jones, Silur. Ostrac. Gothland, 1887, p. 4.

One of the drawings sent from Stockholm shows a beautiful, large, suboblong, reticulate Primitia without a sulcus. It is near P. valida, J. \& H., and, indeed, in one of the varieties of that species the sulcus is obsolete, namely var. breviata (op.

Ann. \& Mag. N. Hist. Ser. 6. Vol. i. 
cit. pl. xiv. fig. 8). The ventral margin of $P$. grandis has a delicate punctation, due apparently to the meshes of the ornamental network coming against the raised marginal rim.

From Frợjel.

5. Primitia reticristata, Jones.

(Pl. XXII. figs. $15 a, 15 b, 15 c$.)

Primitia reticristata, Jones, Silur. Ostrac. Gothland, 1887, p. 5.

This is closely allied to P. cristata, J. \& H. (Ann. \& Mag. Nat. Hist. ser. 3 , vol. xvi. 1865 , p. 420 , pl. xiii. fig. 1). It differs, however, somewhat in outline, being more semicircular in its contour, and especially in having a beautifully reticulate surface.

About twelve specimens were among those sent in 1886 .

From Fröjel.

\section{Primitia seminulum, Jones.}

(Pl. XXII. figs. $17 a, 17 b$.)

Primitia seminulum, Jones, Silur. Ostrac. Gothland, 1887, p. 5.

This is a variety of P. seminulum, J. (Ann. \& Mag. Nat. Hist. ser. 5, vol. xvii. p. 413 for references, pl. xiv. fig. 14). It is slightly modified, being rather longer than the British specimens. Three or four among the specimens sent in 1886 . From Fröjel.

\section{Primitiopsis, Jones, 1887.}

Primitiopsis, Jones, Silur. Ostrac. Gothland, 1887, p. 5.

This is like Primitia externally, except that the anterior end has a specially smooth area, corresponding with an internal portion, which is partitioned off from the rest of the cavity by a cross wall.

1. Primitiopsis planifrons, Jones. (Pl. XXII. figs. $18 a, 18 b, 18 c, 18 d$.)

Primitiopsis planifrons, Jones, op. cit. p. 5, woodeuts.

Suboblong, with rounded ends; bearing a faint sulcus, together with the subcentral pit, which is normal in Primitia; also another slight furrow is observable in the anterior dorsal region. The convexity is greatest along the ventral region, as is usually the case with Primitio of the group to which 
P. umbilicata, P. valida, and their allies belong; and the ventral convexity, overhanging the margin, hides the continuous row of denticles which borders each valve. The surface is reticulate except at the anterior end. The interior of each valve has a thin cross wall in the anterior region, dividing off about an eighth of the length of the valve from the rest of the interior. This constitutes the generic distinction. The narrow crescentic area of surface, corresponding to the separated portion of the interior, being destitute of ornament and therefore smooth, gives the specific name.

There are eight or nine individuals (from the soft shalebeds of Fröjel) among the specimens sent from Stockholm in 1886.

It is correct to take the smooth end of Primitiopsis for the anterior, because that end has its analogue in the structure of the recent Chlamydotheca, Saussure, although in this living form the partition of the anterior portion is not always so complete, and its outside not so distinctly differentiated from the rest of the surface, as in our Palæozoic specimens.

1*. Primitiopsis planifrons, var. ventrosa, Jones.

(Pl. XXII. figs. $19 a, 19 b, 19$ c.)

Pramitiopsis planifrons, var. ventrosa, Jones, Silur. Ostrac. Gothland, 1887, p. 6.

This is closely allied to the last described, but is remarkable for the relative convexity of its ventral region, its less height, and increased dorsal hollow, making it narrow-oblong and subcylindrical in shape.

Only one specimen occurred among those sent in 1886, from Fröjel.

\section{Extomis, Jones, 1861.}

(Ann. \& Mag. Nat. Hist. ser. 4, vol. xi. 1873, p. 413.)

\section{Entomis Lindstrœmi, Jones.} (Pl. XXII. figs. $16 a, 16 b$.)

Entomis Lindstrœemi, Jones, Silur. Ostrac. Gothland, 1887, p. 3.

An Entomis closely related to others already known, but distinct from them all.

It is ovate-oblong; rounded at the ends unequally, elliptically curved below, and nearly straight above. The sulcus is straight and strong, a little in advance of the middle of the valve. The hinder moiety of the valve is fully convex, steep 
behind, and sloping forward into the sulcus; the front part is not so much swollen and slopes down to the anterior margin.

This form is near to E. dimidiata, Barrande (Syst. Sil. Boh. vol. i. Suppl. p. 513; pl. xxiv. figs. 7, 8, 9), but it is longer, more oblong, and not so convex. E. pelagica, Barr. (ibid. figs. 1-6), is a near ally, but it is too convex and has a tubercle. Among other allies are E. tuberesa, Jones, and E. depressa, Salter (Ann. \& Mag. Nat. Hist. ser. 5, vol. xiv. pp. 391 and 394, pl. xv. figs. 1, 5, 6, 7, and figs. 2-3), but the relative convexities, conditions of sulcus, and other features distinguish them. E. reniformis (Kolmodin) and $E$. Angelini, Jones (op. cit.), are far too round and globose, and the sulcus ciffers also.

I may here remark that Entomis Marstoniana (op. cit. fig. 8) is possibly the same as Kolmodin's E. reniformis (WEfv. K. Vet.-Akad. Förhandl. vol. xxxvi. 1880, p. 135, pl. xix. fig. 2).

Some six or eight specimens of E. Lindstroemi were found in the uppermost limestone of Linde klint (cliff or hill) and Sandarfve kulle (top or hillock). Length nearly 4 millim.

2. Entomis incequalis, Jones.

(Pl. XXII. figs. $20 a, 20 b, 20 c$.)

Primitia incequalis, Jones, Silur. Ostrac. Gothland, 1887, p. 5.

This is a peculiar and relatively large valve, having a Primitian character in its reticulate ornament and being Entomidian in its sulcation. This last feature is very strongly marked, and indeed, I think, exaggerated by pressure, making the two moieties of the valve very unequal in both size and convexity. One is much nore swollen than the other and overhangs the ventral and part of the antero-ventral margin; this larger moiety extending forwards below, and thus lessening the area of the front moiety.

The sulcus reaches the ventral margin, as in Entomidella and Bolbozoe*, but its extent and peculiar sigmoidal curve are most probably partly due to pressure. The hinge-line of the valve is straight within (that is, below the dorsal extensions of the two moieties of the valve); the front margin has a strong dorsal angle, is boldly curved below it, and edged with a raised rim and minute denticles. The postero-dorsal angle has been broken away.

The specimen is unique, among those sent from Stockholm in 1886, and, like most of these, was from Fröjel.

* See Ann. \& Mag. Nat. Hist. December 1884, pp. 400 and 401. 
XI. Achmina, Jones \& Holl, 1869.

(Ann. \& Mag. Nat. Hist. ser. 4, vol. iii. p. 217.)

\section{Aichmina bovina, Jones. (Pl. XXII. fig. 8.)}

Aichmina bovina, Jones, Ann. \& Mag. Nat. Hist. ser. 5, vol. xix. p. 412, pl, xiii. fig. 6.

Some drawings sent from Stockholm, and of one of which fig. 8 is a copy, show a form identical with the British species from the Wenlock Shale, but more delicately toothed along the free margin. It is common in the shale of Fröjel, Gothland, also belonging to the $W$ enlock series.

\section{Bursulella *, Jones, 1887.}

(Silur. Ostrac. Gothland, 1887, p. 7.)

This is a small, bivalved, probably Ostracodal form, with more or less triangular valves, which have one or two hornlike projections on the ventral edge of each valve.

\section{Bursulella triangularis, Jones. (PI. XXII. figs. 5,6.)}

Bursulella triangularis, Jones, Silur. Ostrac. Gothland, 1887, p. 7, woodcuts.

The upper and lower edges of the valves are straight, but the ventral edge is much shorter than the other, and a delicate spike projects from each of its angles. The corners of each valve are somewhat rounded and on the lower edge are marked inside with a series of shallow pits, making a slightly crenate contact-line. In outline this curious bivalve, which is probably an Ostracod, looks like a little subtriangular purse (hence the generic name), widest at the top, and ornamented below with two neat little projections.

It occurs in the Cephalopodan Limestone of Sarnsugn, in Othem, and the uppermost beds of Slite, some twenty specimens having been found.

2. Bursulella semiluna, Jones. (Pl. XXII. figs. $4 a, 4 b, 4 c$.)

Bursulella semiluna, Jones, Silur. Ostrac. Gothland, 1887, p. 7.

Here the valves have a nearly semicircular ventral outline

* Buraca, a purse ; bursula, a little purse; bursulella, a very little purse. 
and a straight dorsal edge, with blunt angles. On each valve two short spikes project from the ventral edge. This is crenated within with small regular pits, making a neatly serrated junction ; the pairs of spikes, opposite one to the other, close against each other when the valves are shut.

Seen sideways this fossil looks like a little halfmoon-shaped equal-ended boat, standing on its convex edge, with two pointed feet instead of a keel.

From the Rhizophyllum-beds of Lau, where it seems to be rare.

3. Bursulella unicornis, Jones. (Pl. XXII. fig. 7.)

Bursulella unicornis, Jones, Silur. Ostrac. Gothland, 1887, p. 7.

Valve triangular, with its dorsal corners rounded and its ventral border narrowing into a long subcylindrical spike. A few specimens have been found in the shale of Fröjel and the Cephalopodan Limestone of Samsugn and Slite.

Note.-My friend Professor Lindström has sent me for examination several small Entomostraca which he obtained lately from a red clay at Wisby, Gothland, belonging to the red marl-shales at the base of Stricklandinia-marls (equivalent to the Upper Llandovery) in Gothland. Among them there is a Beyrichia Klocdeni (with hypertrophied front lobe), Polycope, sp., Leperditia, small sp., Bairdia (?), Pontocypris Mawii, P. Smithii, Bythocypris, spp., Cythere subquadrata (?), and some probably undescribed species. These specimens are from the basement of the lowest known Silurian strata of Gothland.

Note.-Whilst this paper was in the press I received from Herr J. Kiesow, of Dantzic, a paper on some Beyrichice from Gothland, published in the Zeitschr. deutsch. geol. Ges. Jahrg. 1888.

\section{EXPLANATION OF THE PLATES.}

\section{Plate XXI.}

[All the figures are magnified 15 diameters.]

Fig. 1. Kloedenia apiculata, nov. $a$, right valve; $b$, edge view; $c$, end
view. Fig. 2. The same. Left valve.

Fig. 3. The same. Left valve.

Fig. 4. The same. $a$, left valve, with the antero-ventral Iobe hypertrophied; $b$, edge view ; $c$, end riew. 
Fig. 5. The same. Right valve, somewhat damaged.

Fig. 6. Beyrichia clavata, Kolmodin. Left valve.

Fig. 7. The same. Right valve.

Fig. 8. The same. Right valve.

Fig. 9. The same. Left valve; antero-ventral lobe hypertrophied; postero-dorsal angle broken.

Fig. 10. Beyrichia Bolliana, var. umbonata, Reuter. Left valve.

Fig. 11. The same. Right valve.

Fig. 12. Beyrichia tuberculata (Klöden). Old individual, damaged, the antero-dorsal portion having been crushed.

Fig. 13. Beyrichia tuberculata, var. spicata, nov., or possibly a very old individual of $B$. tuberculata (Klöden). Left valve, broken.

Fig. 14. Beyrichia tuberculata, var. spicata, nov. Right valve.

Fig. 15. Beyrichia tuberculata, var. foliosa, nov. Left valve.

Fig. 16. The same. Right valve.

Fig. 17. The same. Extreme variation; right valve.

\section{Plate XXII.}

[All the figures are magnified 15 diameters, excepting those marked otherwise.]

Fig. 1. Macrocypris Vinei, J. \& H. a, carapace, showing the left valve; $b$, edge view; $c$, end view.

Fig. 2. The smme. Right valve, shorter specimen.

Fig. 3. Pontocypris Mawii, J.\&H. a, right valve; $b$, edge view of a valve; $c$, end view of carapace.

Fig. 4. Bursulella semiluna, J. $a$, side view of carapace; $b$, ventral edge; $c$, end view. Magnified 30 diam.

Fig. 5. Bursulella triangularis, J. Side view. Magnified 30 diam.

Fig. 6. The same. Interior of valve. Magnified 30 diam.

Fig. 7. Bursulella unicornis, J. Side view. Magnified 30 diam.

Fig. 8. Zichmina bovina, J. Side view. Magnified 30 diam.

Fig. 9. Thlipsura v-scripta, J. \& H., var. discreta, J. a, side view of carapace, showing right valve; $b$, edge view.

Fig. 10. The same. Left valve.

Fig. 11. Leperditia grandis, Schrenck. a, right valve, small, nat. size; $b$, one of the marginal pits, magnified.

Fig. 12. Primitia lavis, J. $a$, left valve of carapace; $b$, edge view of carapace.

Fig. 13. Primitia stricta, J. $a$ and $b$ as above.

Fig. 14. Primitia grandis, J. $a$, carapace, showing left valve; $b$, ventral view; $c$, end view. Magnitied 30 diam.

Fig. 15. Primitia reticristata, J. a, carapace, showing right valve; $b$, dorsal view; $c$, end view.

Fig. 16. Entomis Lindstrceni, J. a, left valve; $b$, dorsal edge. Magnified 5 diam.

Fig. 17. Primitia seminulum, J. $a$, right valve; $b$, dorsal view.

Fig. 18. Primitiopsis planifrons, J. $a$, left valve; $b$, dorsal view ; $c$, edge view of carapace; $d$, interior of left valve.

Fig. 19. Primitiopsis planifrons, var. ventrosa, J. a, right valve; $b$, dorsal edge; $c$, end view of carapace.

Fig. 20. Entomis inceualis, J. a, right valve, probably somewhat short. ened by pressure; $b$, dorsal edge; $c$, front end. 